REFLECTIONS ON GLOBALIZATION

\title{
GLOBALIZATION AND THE CONTINENTAL PHILOSOPHIES OF THE ENLIGHTENMENT: REQUESTIONING THE SYNTHETICAL INCORPORATION OF DICHOTOMIES
}

\author{
Abdelmajid Ridouane \\ Ibn Zohr University
}

\begin{abstract}
Though this paper fully agrees that the ongoing project of globalizing world identities is an offshoot of today's boom of state-of-the arts technologies, it tries to also argue that it is an advanced stage of the intellectual continuum of Enlightenment's universalist grand narratives. Of the narratives of the Enlightenment that I choose to focus on, are seventeenth century imperial 'liberalism' of John Locke (1632-1704) and eighteenth century humanist 'globalism' of Immanuel Kant (1724-1804). The Lockean 'liberalist' and Kantian 'globalist' ideals seem to have been - for the last three centuries - at the backdrop of continental politics and philosophical thoughts preoccupied with the 'World Citizenship' project. I also try to argue that its enduring alias - globalization - has been kept feasible through the little spoken of but constantly operational Hegelian dialectic. Its capacity to insulate old models of classical political theories against obsoleteness occurs through the constant negotiative conflicting theses out of which integrative syntheses emanate. The recent Western Europe's far-right maintenance of a Kantian fear - mongering 'status naturalis,' the border - effacing demise of national sovereignty, and the rise of neoliberal globalization intimately correlate. An in medias res recapitulation of Kant's 'World Citizenship' seems to be the 'end of history's' final synthesis.
\end{abstract}

Keywords: Enlightenment, Hegelian dialectic, globalization, nationalism, liberalism, corporate capitalism.

E Pluribus Unum

\section{Introduction}

The discussion of this article's proposed problematic is premised on the assumption that identity politics in a global context - albeit a seeming offshoot of today's boom of stateof-the arts technologies - are in point of fact an intellectual continuum of the otherwise Lyotardian allegedly disposable seventeenth and eighteenth century philosophical universalist grand narratives. Without meaning to undermine the fact that several 'contem-

Journal of Globalization Studies, Vol. 10 No. 2, November 2019 3-20

DOI: $10.30884 / j o g s / 2019.02 .01$ 
porary theorists are converging on the position that globalization is a distinguishing trend of the present moment' (Kellner 1998: 2), I seek to argue that it simultaneously is - together with the gradually homogenized digital identities that populate it - an advanced stage of the evolutionary political thought of the Enlightenment.

Without the various philosophical narratives of the Enlightenment, there may theoretically not be much intellectual and philosophical resort to serve the project of globalizing world identities today. Among these, I will focus on seventeenth century imperial 'liberalism' of John Locke (1632-1704) and eighteenth century humanist 'globalism' of Immanuel Kant (1724-1804). Because the range of philosophical arguments advanced by the two philosophers is broad, this article will focus mainly on John Locke's Two Treatises of the Government (1690), and Immanuel Kant's Perpetual Peace (1795). These two philosophical treatises were and still are solid references in contemporary globalist politics. As James Tully argues, 'three hundred years after its publication, the 'Two treatises' continues to present one of the major political philosophies of the modern world... it provides a set of concepts we standardly use to represent and reflect on contemporary politics' (Tully 1993: 137). Arguably, this started in the eighteenthcentury US Declaration of Independence (a universal exportable model of democracy) that referenced John Locke's human inalienable rights to life, freedom, and property grounded in the Two Treatises, way down to the twentieth and twenty-first centuries' cosmopolitan ideals that significantly reference Immanuel Kant's Perpetual Peace. As briefly as is consistent with clarity, I try to argue that the Lockean 'liberalist' and Kantian 'globalist' projects (with all the different interpretations they have triggered) have been - for the last three centuries - at the backdrop of continental politics and philosophical thoughts' obsession with the world citizenship project. Today, the gradually crystalizing weakening of the nation-state and the gradual demise of national sovereignty seem to be, among other, a proof that Enlightenment's borderless imperial globalism never was a thing of the past. The twenty-first century identity and identity politics are intimately entangled with this two century-old forward looking project of which colonial enterprise seems to have been a significant episode.

I also try to argue that globalization, which (in)directly emanates from the Lockean and Kantian political philosophical treatises of the Enlightenment, has been kept a feasible project (in different fields and study areas) through the little spoken of but constantly operational Hegelian dialectic. The post-modernist Lyotardian argument that the Western grand narratives are obsolete and abandoned seems to be imminently challenged by the somewhat little spoken of Hegelian dialectic's capacity to insulate classical models of political theories against obsoleteness. The continuity of these models is engineered through the progressivist integration of aging dichotomies, which produces controllable neo-orders without so much annihilating their precedents. Coradetti (2009: 47) assumes that 'philosophical discourse, historically, has often proceeded through progressive dichotomies, as for instance the dichotomies of subject and object, real and ideal, physical and metaphysical, the "is" and the "ought". These are made to interact in a conflictual logic that must produce an integrative synthesis. In other words, through the Hegelian dialectic, especially in Western academia, the various theories, schools of thought, dogmas, etc. that have been established, have constantly been by default accessible to integration. Once they are established as mainstream, they gradually turn to ne- 
gotiable syntheses when eminent oppositional stands materialize. The 1960s and 70s post-modernist theories and relevant postcolonial theory as well as the experimental fields of arts and media are some of the aesthetic and intellectual hubs where the playful integration of opposites has been most apparent. The same paradigm is clear at the economic level with all the massive deterritorialized and border-crossing monetary and financial institutions systematically working towards fusion, integration, and border removal. Even in more delicate sectors such as religion, the ecumenical movement and interfaith dialogue, which are the two facets of the same New Age/world religion integrative system, have garnered growing international substantiation. How this integrative system emanates from the teachings of freemasonry, of which John Locke, himself, was - according to Claude E. Jones (1966: 73) - 'one of the editors of the very first Masonic magazine (The Gentleman's Magazine),' may be deduced from the words of the $33^{\text {rd }}$ degree mason Manly P. Hall who states: 'The age of boundaries is closing, and we are approaching a nobler era when nations shall be no more; when the lines of race and caste shall be wiped out; when the whole earth shall be under one order, one government, one administrative body' (Hall and Blight 1957: 463).

Instances that may help to expand on this remarkable amalgamation and integration of opposites are abundant. One of these, which is relevant to the present article's concerns, is Paul Kelly's (2015) recalling the reconcilability of Nationalism and Liberalism into Liberal Nationalism. The fusion of these two Western ideologies directly impacts how the issue of identity and identity politics are being approached in globalist rather than particularist or pluralistic terms. This and similar dichotomy integrative and, consequently, border erasing theories, which have been tooled in political economy and political theory, have been preparing the grounds for a gradually crystalizing Kantian ambition to establish 'peace' through the transformation of national sovereignty into globalist supranational institutions (the League of Nations, the UN, the IMF, the World Bank, etc.), and the relevant Lockean liberalist ambitions, as will be detailed later. Today, the homogenization of the world populations through NGO and other institutional promulgations of the globalist ideology is stark. Globalization (like its predecessor colonialism and contemporaneous imperialism) appears to be a product of the Enlightenment: the humongous intellectual nucleus for outward looking continental ambitions.

\section{Hegel and the Long-Standing Clash of Dichotomies}

In the lecture given at the John W. Kluge Center, as a follow-up to the edited volume The Jesuits and Globalization: Historical Legacies and Contemporary Challenges (2016), José Casanova (2017) queries: 'Either globalization began yesterday or is a continuation of modern Western hegemony.' Because it is happening in 'this period of transition, in a borderlands between two epochs, globalization signifies both continuities with the past, with modernity and modernization, as well as novelties of the present and the already here future' (Kellner 1998: 25). The capacity to occupy 'borderlands between two epochs' (i.e., to be an offshoot of the past, and a political butler that ushers in the future) is guaranteed by the dialectic. It democratically delineates an amorphous zone/borderland between two conflicting models, which permits continuity.

For many, the dialectic design of Georg Wilhelm Friedrich Hegel (1770-1831) may somehow reductively be defined as a rational method for resolving the conflicting logic 
of two opposites, first through an understanding of each pole; second, through the magnification of two of its conflicting aspects, third, through the negotiation of a synthetic resolution of the conflict. To the critics of the Hegelian dialectic, in which this paper is interested (more than discussing what Hegel himself intended by the dialectic), this process is ominous. To these critics, it threatens to be politically tooled in order to bring desired change or restore an Ordo Ab Chao, (order out of chaos), through perpetuating conflict while eventually disempowering either pole. Within the dialectical process the outcome/synthesis, itself, will turn into an individually standing neo-thesis that will have to necessarily be knocked against (therefore again disempowered) by another antithesis in order to create a new synthesis, and so on and so forth ad-infinitum. But according to Coradetti (2009), the Hegelian method is not so much concerned with synthesizing a resolution out of conflict as it is to recapture unity underlying distinctions. He states:

Perhaps, the first modern voice to have rejected the so-called 'abstractions of the intellect' authoritatively was Hegel, in the course of his attempt to recapture unity underlying distinctions, through the dialectical work of reason. However, even if Hegel's experiment still inspires some parts of current debate, in general, contemporary perspectives are still permeated by methods based on category oppositions, leading to a fragmented reconstruction of reality (Coradetti 2009: 47).

Unlike Corradetti who sees through the Hegelian dialectic a quest for an underlying unity that solves the inherent conflict in polarized distinctions, Pierre Bourdieu (1998) draws attention to the strategic attribute of this intellectual occurrence, which he calls 'the reconstruction of genesis'. He postulates:

by bringing back into view the conflicts and confrontations of the early beginnings and therefore all the discarded possibles, it retrieves the possibility that things could have been and still could be otherwise. And, through such a practical utopia, it questions the 'possible' which, among all others, was actualized (Bourdieu 1998: 40).

The questioning of the 'possibles' and the authority to rekindle conflict within the actualized and established 'possible' is fundamental. It helps to introduce the complementary assumption that the rigid reduction of complexity to a pair of constructed $o p$ posing forces endows the hegemonic regimes, and powerful parties in the hands of whom control mechanisms converge such as both the nation state or the border crossing corporate conglomerations) to tamper with the given 'possibles' and the status quos. The will to power swings from the stronger binary which has the capacity to normativize the political, philosophical, ethical, and economic realities that rationally emanate from it (such as in liberal nationalism instead of national liberalism, as mentioned previously). Instead, the systematic dilution of a powerful binary with its antidote results, at least in a democratic context, either in its unavoidable disempowerment through a negotiated third space, or in the creation of a new order that seems in the given state of affairs as the rational compromise out of the conflict. In both cases, possibilities for control and monopoly are not only present in the caliber of the compromise reached, but also in the possibility of provoking non-existent conflict to reach the compromise. 
This claim is legitimate even if the negotiation of an integrative synthesis is triadic instead of dualistic. Henri Lefebvre (1991: 228), for instance, claims that instead of dualities, 'the global level mobilizes triads, tripartite conflicts or connections.' But he also maintains that

social space can never escape its basic duality, even though triadic determining factors may sometimes override and incorporate its binary or dual nature, for ... is not social space always, and simultaneously, both a field of action... and a basis of action? ... Is it not at once actual (given) and potential (locus of possibilities)? Is it not at once quantitative .... and qualitative ...? (Lefebvre 1991: 191) (italics in original).

This quote is a good example of how the Hegelian dialectic may refer both to the phase of unity prior to the constructed category oppositions as well as to the postcategory opposition phase - the unity/synthesis that is a result of the integration of these categories. The obsession with unity in quest for a world consciousness (which is, as I try to argue, also a distinctive component of globalization) is not unique to Hegel. His contemporary Novalis (Georg Philipp Friedrich von Hardenberg) (17721801) whose issue with the Kantian separation of the Individual I and the Absolute I (i.e. God) led him to propose that

we have access to both kinds of existence, although imperfectly, and can combine them, although never completely. The task of doing so is ... the human vocation. Taking up this task not only allows human beings to integrate into their selves aspects of their greater self (or God) from which they are currently alienated, but also facilitates the original purpose of the world as the gradual development from an absolute, undifferentiated, blind unity, to a community of individuated entities conscious of their true spiritual nature (Ezekiel N.d.; emphasis mine).

It may be no pedestrian analysis to argue that Hegel's and most of the Enlightenment philosophers' and thinkers' theoretical work on the relationship between the two poles of the binary oppositions (instead of the anatomic analysis of each pole in itself) is, for example, a forerunner of more expanded theoretical works that later on would inform Saussure's Structuralism and Strauss's Structural Anthropology (as theses). From a historical perspective, Structuralism would appear to be an authorized foundation of the divisive modernist dogma that has ever since the Enlightenment constructed the world in binaries of master and slave, civilized and savage, enlightened and reactionary, etc. Along the same historical timeline, subsequent post-structuralist and deconstructivist theories may - from the proposed perspective - be par-excellence progressivist antithetical responses. From a historical viewpoint, the late 1960s and 70s (significantly also the birthdate of border-effacing neo-liberalism) post-modern and post-structuralist deconstructivist phase, canvassed liminality and fluidity as essential models of identity (re)formulation. It is itself a transitional juncture between the classical macrosociological approach to identity definitions and the contemporary remodeling globalist fusion of world virtual identities into the blogosphere.

The post-modern, post-structuralist and other revolutionary border erasing and dichotomy-integrative theories of the sixties may thus be seen as historical phases of 
a massive intellectual campaign in the thesis/antithesis dialectic, where radical dichotomies cease to be maintained, and consensus over debated problematics may be reached mainly through hybrid integrations. How these theories culminate in a (both material and immaterial) post-modern 'border' melt-down of metanarratives has been not only acknowledged but also celebrated. Today, the at-once integrative negotiations to which this melt-down process has led promotes two main universalist hegemonic orders. The first is an economic order that has gradually homogenized world financial markets populated by mass-consumer collectives 'shopping' for, among other, the benefit of the counterpart supranational conglomerations of corporate companies. In discussing the economic implications of contemporary society being postmodern, J. Thomas Gomez-Arias and Laurentino Bello Acebrón (2001: 8) postulate that 'in this postmodern society, economic relationships adopt new meanings and management needs to take new directions.' Two of these, they further argue, are:

the area of communications (e-mail, video conferencing, mobile phones, etc.), [which] widens the possibilities for expression of individuality, diversity, flexibility and personal independence, while, at the same time, limiting the freedom of personal interaction... [and] the so called technology companies involved in different ways of connecting distant parties, marketers of consumer products and their clients (Ibid:: 11).

The second is an ideological an ecumenical order. It is not at all extraneous to the monism of Hegel and Novalis, and their predecessor Christian Wolff (1679-1854), the German Enlightenment philosopher and monist trailblazer. As the $33^{\text {rd }}$ degree mason, Manly P Hall straightforwardly puts it: 'Christ, Buddha or Mohammed, the name means little, for he [the freemason] recognizes only the light and not the bearer. He worships at every shrine, bows before every altar, whether in temple, mosque or cathedral, realizing with his truer understanding the oneness of all spiritual truth' (Hall 1984: 28; my emphasis).

The omnipresent obsession with dualities and oppositional poles throughout both the old and new Western philosophical dialogues ('Cartesian anxiety' included) is not only profitable to the Hegelian method; it also gives it legitimacy and intellectual impetus. Western (political) philosophy is profoundly marked by the Hegelian dialectical intellectual history's 'evolutionary process [that] was neither random nor unintelligible, even if it did not proceed in a straight line' (Fukuyama 1992: xii). Akin to Francis Fukuyama's conclusions concerning the 'end of history', this dialectic seems to have, in the same fashion, gradually capped in the globalist stampede that the world is experiencing today. It is most visibly at work in how the grand themes of politics, economy, and history may be controlled to desirable syntheses through this evolutionary nonrandom process.

One of the finest problematics embedded to the Hegelian dialectic, akin to the Hobbesian and Kantian 'natural law', is its parameterizing its field of intellectual pursuit into blocks that are progressive only through 'imagined' conflict, since the overall rationalization of the polarization is a subjective construct. For this, the complexity embedded in each block has to necessarily be suspended or overlooked for the dialectical process to take place. Another problematic is the paramount vitality of conflict over symbiosis, even if both conflict and reconcilement coexist in the two poles object of the 
dialectical process (or in Corradetti's terms the 'attempt to recapture unity underlying distinctions' (Corradetti 2009: 47). For this, apparent disparity provokes the conflict, and 'just enough' commonality gives it validity. Otherwise, there cannot be significant dialectic engagement between two opposites if a priori they have nothing in common. There are two apparent outcomes to this condition: the first is the suspicious impact it has on the modernist intellectual as well as political history, which views interaction mainly in terms of conflict. The second is that - at least in my analysis of how Western grand narratives have been synthesized - theoretical obsession with 'conflict' considerably obscure the internal complexities harbored in each narrative.

\section{Enlightenment Ideals 'You-Kant-Locke' in Time and Space}

In main stream criticism of Immanuel Kant's philosophical ideals of the Enlightenment, Kant is celebrated as an early promoter of cosmopolitanism, advocating unity without undermining plurality. Kant's ideals are, on the other hand, skeptically approached as a covert promotion of globalism which, in his own terms, sees that 'the human race can gradually be brought closer and closer to a constitution establishing world citizenship' (Kant 2003: 7; my emphasis). This assumption seems to implicitly evolve from Kant's and other continental philosophers' quintessential premise that conflict and quarrelsomeness - rather than co-existence - are inherent to neighboring states and that 'peoples, as states, like individuals, may be judged to injure one another merely by their coexistence in the state of nature (i.e., while independent of external laws)' (Ibid.: 5). In the framework of continental relations, Emmanuel Kant, like his predecessor Thomas Hobbes's bellum omnium contra omnes (war of all against all), thus assumes that the state of nature is one of threat and anarchy. It, consequently, requires the imposition of order. In Kantian terms, at least those that may be teased out from his own juxtaposition of the dualistic peace and war, the state of peace is not 'the natural state (status naturalis); the natural state is one of war... A state of peace, therefore, must be established, for in order to be secured against hostility it is not sufficient that hostilities simply be not committed' (Ibid.: 3). Significantly, Kant also proposes that a 'league of nations' (Ibid.: 5) should prompt the otherwise missing peace among the conflict-oriented neighboring nations.

While it may be a surprise that a century and a half later a post-World War II Kantian by-the-letter 'League of Nations' would indeed be established, what is more telling is that it is dialectically synthesized from a ravaging World War II (the antithesis of peace). This was true about World War I, too. On January $8^{\text {th }} 1918$, Woodrow Wilson gave a speech at the American Congress that was composed of 14 points. The first point was an expression of liberalist ambitions (absolute freedom of navigation, removal of economic barriers, reduction of national armaments, and the last point was a draft constitution of 'general association of nations' (Wilson 1918: 8) with the purpose of guaranteeing peace among nations (not sarcastically) 'against the Imperialists' (Ibid.: 8). Ever since, the world has steadily headed to 'states amalgamated into one,' which Kant considers a deviation from the peace-advocating 'league of nations.' In his own words:

'The Law of Nations Shall Be Founded on a Federation of Free States' ...This would be a league of nations, but it would not have to be a state consisting of nations. This contradicts the presupposition, for here we have to weigh the 
rights of nations against each other so far as they are distinct states and not amalgamated into one (Wilson 1918: 5; emphasis mine).

Under the auspices of what Hulme and Lordanova call the Enlightenment 'Comparative Project,' it would be useful to recapitulate on the fact that Kant, like Rousseau, Diderot, and other writers and continental philosophers of the Enlightenment were not literally continental because they only read about the 'violent' non-European worlds that they speculated about. Hulme and Lordanova state that 'the philosophical reflection on the nature of political society was often carried out via contrasts between European institutions and the supposed "state of nature" witnessed by ... European travelers to the new worlds of America and, later, the South Seas' (Hulme and Lordanova 1990: 8). The kind of relation that existed between the early Western political philosophers and the subsequent political regimes is, therefore, ambiguous, to say the least. For one, in 1900 , only one century after Immanuel Kant had written his peace promoting treatise 'Perpetual Peace' (i.e., 1795), almost all of the African continent was colonized by the logic of military force and subjugation. To put it in Edward Said's (1993) terms

in 1800 Western powers claimed 55 per cent but actually held approximately 35 per cent of the earth's surface, and by 1878 the proportion was 67 per cent, a rate of increase of 83,000 square miles per year. By 1914, the annual rate had risen to an astonishing 240,000 square miles, and Europe held a grand total of roughly 85 per cent of the earth as colonies, protectorates, dependencies, dominions and commonwealths. No other associated set of colonies in history was as large, none so totally dominated, none so unequal in power to the Western metropolis (Said 1993: 8).

In other words, while - at its core - colonial enterprise is an advanced level of the proclaimed civilization (read peace) promoting ideals of the Enlightenment, it paradoxically brought war unto peaceful nations, as we shall see with John Locke as well. Kant who - faithful to the 'Comparative Project' ideology and the divisive vision of the modern world as distanced from 'Uninhabitable parts of the earth - the sea and the deserts - [that] divide this community of all men' - cautions the 'inhospitality of the inhabitants of coasts (e.g., of the Barbary Coast) ... or the inhospitality of the inhabitants of the deserts (e.g., the Bedouin Arabs) who view contact with nomadic tribes as conferring the right to plunder them, is thus opposed to natural law' (Kant 2003: 7). He, therefore suggests that communication be established between the civilized West and these distant parts of the world [which] can come into peaceable relations with each other, and these are finally publicly established by law' (Kant 2003: 7). Thus, 'the idea of a law of world citizenship is no high-flown or exaggerated notion' (Ibid.: 8; emphasis mine). Even more, before its demise, colonial regimes had broken colonized nations into smaller states, which was not only a major cause for the inflammation of border wars/conflicts in Africa and Asia in the postcolonial era, but it also went in opposite direction of the highly celebrated continental philosophers of the Enlightenment. The ambiguity seems to persist equally because the Kantian warning against 'the amalgamation of states into one' seems to be in effect through neo-liberal globalization and its political, cultural, economic, military, and technological ubiquitous trajectories as well as its institutional drivers. According to James Tully (2008), 
the Enlightenment/Kantian 'globalist' world-view is, 'imperialistic' in the sense of being, among other, 'the direction of nature and history and the precondition of an eventual, just, national and world order; and it is imposed on non-European peoples as their cultural self-understanding in the course of European imperialism and federalism' (Tully 2008: 27).

The critics labelling Locke as an imperial liberalist philosopher of the Enlightenment is premised on the account that Locke and other philosophers of the period had already established the theoretical foundations of the liberalist dogma that would proliferate as of the nineteenth century. Akin to the philosophical critics' division over Kant's 'cosmopolitanism,' theorists and political history's analysts are also in clear disagreement about Locke's liberal ideals. For one, Locke's 'liberalism', which some analysts qualify as imperial, as I will elaborate shortly, seems to be trapped between his milderthan-Hobbes and Kant's philosophical thoughts on the state of nature, which he defines as men living 'together according to reason, without a common superior on earth, with authority to judge between them' (Locke 2003: 108), and his thoughts on natural law which uncompromisingly stresses the freedom and the various rights to which an individual is entitled regardless of his race or political orientation. Locke clearly states:

The liberty of man, in society, is to be under no other legislative power, but that established, by consent, in the commonwealth; nor under the dominion of any will, or restraint of any law, but what that legislative shall enact, according to the trust put in it (Locke 2003: 126).

In one of the chapters ahead, Locke elaborates:

This legislative is not only the supreme power of the commonwealth, but sacred and unalterable in the hands where the community have once placed it; nor can any edict of anybody else, in what form soever conceived, or by what power soever backed, have the force and obligation of a law, which has not its sanction from that legislative which the public has chosen and appointed (Ibid.: 175).

Locke is an excellent illustration of the disjuncture between his own 'liberalist' ideology that promotes freedom of speech, subject rights, and right to ownership, on the one hand, and colonialism or slavery, on the other. Even if it could arguably be said that 'liberalist' ideology did not support colonialism and slavery, at least it harmoniously coexisted with them as contemporaneous contradictory systems. In the first chapter of the second treatise of 'Two Treatises', Locke states that

there cannot be supposed any such subordination among us that may authorize us to destroy another, ... Every one, as he is bound to preserve himself, and not to quit his station willfully, so by the like reason, when his own preservation comes not in competition, ought he, as much as he can, to preserve the rest of mankind, and may not, unless it be to do justice to an offender, take away or impair the life, or what tends to the preservation of life, the liberty, health, limb, or goods of another (Locke 2003: 102).

One meaningful trait of Locke's philosophical thought concerning his liberalist orientations may be inferred from Hulme and Lordanova's claim that though 'no major 
Enlightenment figure had direct experience of the colonies but several, foremost amongst them John Locke, worked closely with the private and state bodies which were responsible for formulating the colonial policies of European countries during the period' (Hulme and Lordanova 1990: 17).

Richard Tuck, Professor of Government Department at Harvard and a premier scholar of the history of political thought writes:

There has never been any doubt about Locke's interest in the European colonizing and exploring activity, and in the relations between European states... in addition, as is well-known, from 1669 onward, he was intimately involved in the development of Carolina... he was himself an investor in the Royal Africa Company and in the Bahamas Islands (which were given to Carolina in the 1670s) ... An island near Charleston, now called Edisto Island, was originally called Locke Island (Tuck 2002: 167).

Duncan Ivison equally argues that:

There is no question of reducing Locke's intentions in the Two Treatises, in particular, entirely to this colonial context. But to simply ignore the internal and external evidence of his engagement with the arguments, policies and politics of England's colonial expansion would be equally negligent (Ivison 2003: 86).

Ivison's further insights on Locke's philosophy that he elaborated in order to correlate between liberalism and colonial expansion are worth considering. These insights do not only locate the embryonic stage of liberalism in Locke's philosophical thoughts (especially his commitment to individual ownership and market relations), but Ivison also qualifies them - again - as ambiguous. The interesting trait of this ambiguity - as I am trying to argue - is its capacity to amalgamate and mix the old European republican vindication of the common good, and the emerging promotion of individual freedom and the supremacy of the logic of the market. Locke, as Ivison further argues, seems to be convinced 'that the well-being of England depended on her securing a foothold in world trade, and that meant an effective and productive system of colonies and plantations, among other things' (Ivison 2003: 93; my emphasis). Defending Steve Pincus's (1998) original thesis in 'Neither Machiavellian Moment nor Possessive Individualism: Commercial Society and the Defenders of the English Commonwealth,' Ivison argues that Locke's 'project can be seen as emblematic of an attempt by many political thinkers during the mid to late seventeenth century to blend a commitment to some of the principles and ideals of the humanist republican tradition with the newly emerging commercial society' (Ivison 2003: 95). The notion that 'human society consists of market relations [which] necessarily implies that an individual's humanity is a function of his freedom' is an 'identifiable social assumption which is common to the main seventeenthcentury political theories' (Macpherson 1964: 264).

The disjunctive backlash that problematizes Locke's liberalism and his advocacy to colonial enterprise is evident in his obligation to grant natural rights and individual freedom 'to [the Indians] but denies their communities the status of civil societies' (Ivison 2003: 98). This contradiction that the embryonic phase of liberalism endured is reflected in the more evolved phases of global neo-liberalism. Today, Neo-liberal Globalization, which 'has been a U.S. state project, framed at the behest of U.S. corporate elites, allied 
policy-makers, and regime intellectuals' (Antonio and Bonanno 2006: 2), faces the same dilemma as it draws 'on an American exceptionalist tradition that portrays the U.S. as modernity's "lead society," [which] attaches universal significance to its values, policies, and institutions, and urges their worldwide diffusion. All three traditions ignore or diminish the importance of substantive equality and social justice' (Ibid.: 3).

\section{Nationalism/Liberalism and the Enlightenment's Fearful 'State of Nature'}

At the blue print level of the present article's argument rests a set of dystopian convictions that the traditional/national paradigm, had to have been a systematically exaggeratingly dented construct. The ways the different types of nationalisms that any researcher may probe, almost all allude to narrow-minded material or immaterial selfcenteredness that cements together nationally 'imagined communities.' According to Benedict Anderson, for example, the turn of nationalist consciousness in sixteenth century Europe had its direct and indirect causes in capitalist print industry's marketing profit from capsizing the dominant Latin, and ushering previously dispersed dialects (such as French and German) to ranks of power. The fragmentation of Latin into a variety of different languages

created unified fields of exchange and communication below Latin and above the spoken vernaculars. Speakers of the huge variety of Frenches, Englishes, or Spanishes, ... gradually became aware of the hundreds of thousands, even millions, of people in their particular language-field, and at the same time that only those hundreds of thousands, or millions, so belonged. These fellowreaders, to whom they were connected through print, formed, in their secular, particular, visible invisibility, the embryo of the nationally imagined community (Anderson 2006: 44).

Ever since, nationalist consciousness has often gestured to two particularity and ambiguity. A dialectic where nationalism and violence are mutually inclusive (such that violence may lead to nationalism, the very same way nationalism may lead to violence) has widely circulated. Whether the global wars that have occurred in twenty and twenty first centuries may be due to a series of objective determinants, or whether these wars have been a result of false flag operations, nationalist consciousness has been under vigorous attack as well as simultaneous solid construction, hence its ambiguity. The complex analysis of national identity formations is, therefore, liable to head to indecision since nationalistic identification is both a reaction to and a construct of imperialistic domination ever since the post-French Revolution movements' retaliation against Napoleonic imperialism as well as a reaction to and a construct of both real and fictitious foreign threats.

Most nationalisms that have recently emerged in the US, the EU, and the previously colonized countries are discursive products of violence, instability, fear, and xenophobia. The interesting difference between the two first world and third world nationalisms is that the former is a product of violence, the latter an instigator. In the third world countries, nationalistic self-identification has been largely undermined because it has been firmly tailored to oftentimes controlled inflammation of ethnic consciousness and intolerance. Third world nationalisms/collective identifications, albeit not homogenizable, still unde- 
niably share the same underlying attributes coopted in tautological insinuation to ideological narrowness and internal convergence that provoke desire to escape. Anthony Smith summarizes the problem of nationalism as a collective phenomenon in the fact that 'many people, as a result of the nationalist drive, find themselves divided in their allegiances between loyalty to the state to which they belong, and a lingering but explosive solidarity to the ethnie of their birth and upbringing. Similarly, the rise of the nation has created fertile soil for separatism, as many ethnie aspire to become nations' (Smith 1988: 130). While this is also true of some European countries, it is, nonetheless not the recent prevalent trend.

Most of the criticisms that have been, therefore, levelled at nationalism seem to be pointing to the constructed dark side of such an identification. In reference to the world of academia, I presume, the nineteen sixties social and critical theories implosion have massively contributed to resisting the border building nationalistic paradigms. A massive attack was mainly launched on the Japanese, Italian, and German experiences with narrow-minded nationalisms that were violent, tyrant, and irrational. The dark side of nationalism has been manufactured to irrationalize its usefulness.

Against all odds, however, the extreme right particularist ideologies have been gaining considerable grounds both in Europe and the US. The recent American president Donald Trump's 'Make America Great Again' certainly raises more than one disconcerting question because of the land and aerial border simultaneous exclusionist complements it escorts. The figurative landscape of building a wall that is meant to deter South American illegal immigrants, and Trump's 'Muslim Ban' enhance the exact sense of populist nationalism that is undermined, but that is, as it were, rampant and exclusive to powerful nations. That is, the American president's undiplomatic speeches substantially increase the very type of exclusionist nationalism that is gradually taking over the political and the social international landscape. It does not positively celebrate it. It further stirs its dark sides. It establishes a tense atmosphere of global International relations where the American rhetoric of war unilaterally addresses the people of the world as potential threats to US homeland security. This type of fear-mongering rhetoric, promotes a high degree of defensive nationalism which goes into swift particularist metastasis that threatens multiculturalism. It simultaneously also imposes an otherwise absent consensus because 'as America becomes an increasingly multicultural society, it may find it more difficult to fashion a consensus on foreign policy issues, except in the circumstances of a truly massive and widely perceived direct external threat' (Brzizenski 1997: 211). This sense of post 9/11 extremist nationalism which rests on a reminiscent allusion to the Kantian 'status naturalis' promotes that the United States of America is under attack. It necessarily needs freedom-compromising security measures. Though it cannot be argued that it is a new trend in nation-state high priority internal affairs, likewise restrictive political manoeuvers permanently threaten, such as has been the case in Nazi Germany, to serve ends other than national security. It can be a powerful tool of exclusion, civil rights violation, stigmatization of under-represented ethnic groups, and especially the manufacture of manageable sameness, unanimity, and the coercive homogenization of multi-ethnic groups.

For clarification, it would be useful to refer to Sabanadze's categorization of recent trends of nationalist resurgence into three main types: 
the first has to do with the disintegration of multinational states such as the Soviet Union and Yugoslavia and the accompanying spread of ethnic tensions and in some cases ethnic warfare. The second manifestation is the increasing popularity of nationalist parties, sometimes with a separatist political agenda, among stateless nations of Western Europe. This includes Scotland, Basque Country, Catalonia, and Belgium, where nations within multiethnic states have been voicing demands for secession or renegotiating their statuses within these states toward greater autonomy and self-rule. Thirdly, nationalism increases with the rising popularity of radical right-wing political parties in Western Europe and elsewhere (Sabanadze 2010: 35).

A short glance at recent history, therefore, makes it evident that the overall suspicions directed against particularist and ambiguous nationalisms have been an offshoot of 'controllable' conflict of the twentieth-century colonial enterprise, post-war trauma, international relations and the international economies post-cold war adjustments, and the redirection of the current (post 9/11) internationalized Western political neo-liberal economies which export divergent homogenizing globalist values and import manufactured convergent fear and distrust. This conflict-based ideology has roots in the Lockean, and Kantian/Hobbesian philosophies, as discussed previously. The manufacture of fear in the US and the passing of laws such as the Patriot Act, passed in 2001 interestingly immediately after the 9/11 attacks remain ideologically indebted to the forefathers of the Enlightenment and its establishment of fear, polarity, and conflict as the norm for international relations. Whether this is an unpronounced price that ordinary citizens should pay in an open global world, or whether it is the legalization of population control that the false-flag Hegelian dialectic imposes in the absence of genuine conflict (as also discussed previously) is a debate that is hard to settle. The Enlightenment ideals and their establishment of a tense and precarious state of nature that calls for the imposition of order is inherently encompassing the liability of the stronger party to provoke a conflict that later synthesizes into the capacity to control (of nature itself, of peoples, of threats, information, wealth and economy, etc.). While acknowledging the American citizens' contribution to the massive construction of 'this culture of fear', Geoffrey Skoll believes that 'it is the elites in the centers of world capitalism who have fostered its construction with planning and deliberation. It did not just happen. It did not arise from vague social forces and change. It is possible to lay the main responsibility for this culture of fear at the feet of a relatively small number of powerful people' (Skoll 2016: 27).

Nationalism played a major role in challenging, and therefore, breaking newer grounds upon which neo-forms of liberalism have emerged, without so much totally annihilating an ideology. As a matter of fact, these two trends are historically governed by a low tone intertwine. As Paul Kelly argues, 'much of the early nineteenth century liberalism and nationalism were interconnected. This had an important impact on the subsequent development of liberal political theory and gave rise to the idea of liberal nationalism, an idea that is given its most forceful Anglophone statement in the nineteenth century in the political theory of John Stuart Mill (1806-1873)' (Kelly 2015: 12).

Like nationalism, globalism, too, subscribes to the rule of Enlightenment 'status naturalis'. It, too, needs an external threat rationale. Threats of climate change, water shortage, and terrorism, are essential for promoting world unity since the magnitude of 
the necessary changes might not be efficiently counter-balanced by one sovereign state alone. From the perspective where a Western anti-nationalist advocate is standing, globalist values are generally defended on the premise that they are the ideal solution to immigration and assimilation problems. Unlike nationalism which is a social and political cul-de-sac because it is inward looking, patriotic, and divisive, globalist values promote diversity within a recognizable collective sense of shared identity. This, indeed, is quite accurate until we see how the immigration question is provoked and inflamed by the very dark side of the globalist and neo-liberalist war-promoting order. Today, it is more than just clear that the neo-liberal policies both directly and tangentially aggravate sociopolitical disorders in the countries sources of immigration, be them Latin American, Asian, or African. It may be difficult to prove that the immigration question is instigated by the rule of international conflict in order to pressure the growing European and nationalist particularist mindset, but it is no point of debate that right-wing nationalism in Europe and the US stands as 'a clear reaction against influences of globalization such as growing immigration and movement of labor, decline of traditional industries as well as traditional ways of life' (Sabanadze 2010: 35; my emphasis). Coin flipped, the immigration question, besides the various thorny facets it has, appears to be an antithesis to the nationalist thesis; an instrument of negotiation of the synthesis that the evolutionary forms of globalist values of freedom, mobility, tolerance and acceptance should be the new era's reference to global problems.

Not far from the above-mentioned clash of mainstream dichotomies are relevant attempts to mend the divide such as between universalism, on the one hand, and relativism, on the other, both of which are Western modernist ideologies. To solve the problematic division between cultural rights and liberty rights, this division, too, has to negotiate its way out of the restrictive dichotomy through the same dialectic. Xiaorong $\mathrm{Li}$ suggests that

we can meet the challenge posed by cultural rights (granted as exclusive membership privileges) to their compatibility with liberty rights in at least two ways. First, we can point out that cultural rights are granted to all human beings, though not everyone chooses to exercise them, given that all human beings often are or at least can be members of (diverse) cultures... Secondly, certain classic liberty rights, i.e. rights to freedom to associate, assemble, expression, conscience and religion, are prerequisites, necessary if not sufficient conditions, to effective exercise of the right to culture. Without these liberty rights, one is vulnerable to violation of one's right to have 'exclusive' privileges. Such privileges may be necessary for one to participate in the creativity and development of, and to benefit from, one's culture. This is the consequentialist argument for the integrity of cultural rights with liberty rights (Xiaorong Li 2006: 89; my emphasis).

\section{Conclusion}

Before wrap up, it is important to mention that this paper has been inspired from Bonnie Mann, who, in her Sovereign Masculinity, raises quite a discomforting question. The provoking query goes: 'what if 'the hybrid and fragmentary subjectivities' that postmodern theorists celebrate as liberatory are the vehicles for a new form of sovereignty'? 
On palimpsest background lines, this paper has not subscribed to prima facie divergences such as - to cite only a few - the post-modernist left 'which treat[s] ... universalism with disdain and suspicion, insinuating to it an imperial agenda and offering an alternative program of multiplicity, diversity, and multipolarity' (Berman 2017: 191). Same as the globalist overall undertaking, Postmodernism, itself an ideology synthesized out of the WWI and II antitheses to Modernist rationality and empiricism, at its core is a celebration of border effacement and underplay of distinctions between genres. The philosophical meaning of 'collage' and 'pastiche' combines what might traditionally be perceived as materials that should empirically belong to distinct categories with distinct convenient environments. Celebrating incoherence and playing with nonsense point to the same direction. Nor would this article totally agree that Nazism and Zionism are, as is visible at the surface, antidotes to each other. The frictions that these divergences make at the surface, besides the likelihood that they conceal other kinds of universal alliances, are oftentimes contradicted by the necessary agreements they conceal at the base. More often, they arouse skepticism by the reciprocal dialectical concessions they impose on each other in the negotiation process. One meaningful example is proposed by Edwin Black (2009) who postulates that the anti-Semitic persecution of the Jews by the Nazi regime was in fact 'a turning point for Zionism. The task facing the Zionist movement was to maneuver to the forefront of the international Jewish response and interpose Zionism and Palestine as the central solution to the German Jewish problem' (Black 2009: 185). The same may be said about the frictions between Nazism and Communism. Both triggered Word War II and the Cold War aftermath, out of which the newer order establishing border crossing post-World War II global political institutions synthesized. The political organization (the United Nations) was established in 1945 to replace the 'Kantian' 'League of Nations' project, one year later. Economically, the financial and monetary organizations such as the World Bank and the International Monetary Fund were founded in July and December 1945, respectively. Their most significant attributes are their globalist magnitude and transcendence of sovereign national borders.

This paper has, thus far, tried to pay particular attention to how early modern philosophical assumptions such those of the early 'universalist' Immanuel Kant and 'liberalist' John Locke, as has been discussed, have lived through modern times thanks, among other, to the dichotomy-integrative Hegelian dialectic. For this, globalization may, as a conclusion, be defined as a political, cultural, and economical final phase of the Kantian and Lockean Enlightenment ideals constantly fueled by the evolutionary dynamics of the veteran Hegelian dialectic. It is mainly seen as a synthesis of two modernist grand narratives, namely nationalism (premised on sovereignty and collective affiliation) and neo-liberalism (premised on supranationalism and free individual will). For this, the question that this paper would wish to raise is not whether the nationalist model has a lesser capacity to answer more complicated questions than the multicultural/globalist model. The more disconcerting questions rather are: why have the contradicting facets of the nationalist model especially in the Enlightenment values exporting Western countries come back. Why is it simultaneous and more forcibly juxtaposed to the neo-liberal model and its 'hostility to collective ideologies ... grounded in 
its unequivocal commitment to the absolute supremacy of individual liberty, private property, the free market, and to the assignment of personal responsibility' (Dixon 2017: 5).

In relation to the Enlightenment philosophers' engagement with the 'status naturalis', I maintain that neo-liberal globalization is promoted as a safe and better alternative to the propounded dark sides of nationalism (including pre-Cold War benign anticolonial third world nationalisms), as well as to the eventual failure of some ideals of neo-liberalism. My assumption is that the relevant question of identity is being systematically modelled after the recent prevalent culture of fear and distrust that is being promulgated within the multi-nationalist capitalism's stampede of world financial markets, and its authority over significant networks of politics and media industries. While the conflict under this particular precarious climate of international politics is indeed between the nationalist model and the globalist/neo-liberal model, the fusion of both is not only the solution in sight, but also a highway for the economies that multi-corporate institutions rally for, and the climate of conflict they provoke are for these economies to be kept in place. While, as has been mentioned beforehand, neo-liberalism is an antidote to collective ideologies, the globalist reconstruction of the world's various identities is, paradoxically, also ideological. The New Age, which reminisces on Evolutionary Theory and how man is progressively evolving to an advanced level of god-like consciousness, is largely based on the ecumenical engineering of a one-world unified religious identity. Globalizing education and global classrooms, is another rather effective tool for unifying world cultures, and reconfiguring the worlds various cultures, systems of thought, histories, and ideologies.

In other words, despite all that can be argued for or against the efficacy of the nationalistic model, international politics and multi-corporate economies, including the ones that promote warfare, provoke such an unsolvable paradox when the world populations' fear of the Other is unprecedented, while they are instigated through the multicultural model to debate over channels of mutual understanding, tolerance, and acceptance. This schizophrenic condition has created a world population of solitary and alienated individuals who are quitting the nationalist and religious and cultural specific identification without so much finding serviceability in the celebrated multiculturalist model. Given that after the decomposition of old borders and the task of rebuilding newer models of belonging, consequently, becoming attainable, it may be argued that the post-colonial strive to prove the heterogeneity of identity, and the fragmentation of the self positively serves the new globalist model of reuniting these loosely belonging collectives and fragmented subjectivities within the globalist (i.e. digital) identities.

\section{REFERENCES}

Anderson, B. 2006. Imagined Communities: Reflections on the Origin and Spread of Nationalism. London: Verso.

Antonio, R. J., Bonanno, A., Lehman, J. 2006. Globalization Between the Cold War and Neo-Imperialism. Current Perspectives in Social Theory 24: 1-56.

Berman, R A. 2017. Critical Theory of the Contemporary: Nationalism, Populism, Islamism. Telos 178: 191-193. 
Black, E. 2009. The Transfer Agreement: The Dramatic Story of the Pact Between the Third Reich and Jewish Palestine. Washington D. C.: Dialog Press.

Bourdieu, P. 1998. Practical Reason: On the Theory of Action. California: Stanford University Press.

Brzizenski, Z. 1997. The Grand Chessboard: American Primacy and Its Geostrategic Imperatives. Basic Books.

Casanova, J. 2016. The Jesuits through the Prism of Globalization, Globalization through a Jesuit Prism. In Banchoff, Th., and Casanova, J. (eds.), The Jesuits and Globalization: Historical Legacies and Contemporary Challenges (pp. 261-286). Washington D. C.: Georgetown University Press.

Casanova, J. 2017. Early Modern Globalization Through a Jesuit Prism. Youtube, uploaded by the Library of Congress, 18 August. URL: https://www.youtube.com/watch? $\mathrm{v}=2 \mathrm{JgHdV} 44 \mathrm{H} 1 \mathrm{k}$.

Corradetti, C. 2009. Relativism and Human Rights: A Theory of Pluralistic Universalism. Springer.

Dixon, J. 2017. The Idea of Neoliberalism: The Emperor has Threadbare Contemporary Clothes. Washington, D. C.: Westphalia Press.

Ezekiel, A. N.d. Novalis (Georg Philipp Friedrich von Hardenberg) (1772-1801). The Internet Encyclopedia of Philosophy. URL: https://www.iep.utm.edu/novalis/\#H4/. Accessed February $15^{\text {th }} 2019$.

Fukuyama, F. 1992. The End of History and the Last Man. New York: The Free Press.

Gomez-Arias, J. T., and Acebrón, L. 2001. Postmodern Approaches in Business-to-Business Marketing and Marketing Research. Journal of Business \& Industrial Marketing 16 (1): 7-20.

Hall, M. P. 1984. Lectures on Ancient Philosophy: A Companion to the Secret Teachings of All Ages. New York: Penguin.

Hall, M. P., and Blight, R. E. 1957. The Lost Keys of Freemasonry: Or, The Secret of Hiram Abiff. Macoy Pub. and Masonic Supply Company.

Hulme, P., and Lordanova, L. 1990. The Enlightenment and Its Shadows. New York: Routledge.

Ivison, D. 2003. Locke, Liberalism and Empire. In The Philosophy of John Locke: New Perspectives, by Peter. R Anstey, 86. New York: Routledge.

Jameson, F. 1985. Postmodernism and Consumer Society. Postmodern Culture: 111-25.

Jones, C. E. 1966. John Locke and Masonry: A Document. Neuphilologische Mitteilungen (Modern Language Society) 67 (1): 72-81.

Kant, I. 2003. Perpetual Peace: A Philosophical Sketch. Indianapolis: Hackett Publishing.

Kellner, D. 1998. Globalization and the Postmodern Turn. Globalization and Europe: 23-42.

Kelly, P. 2015. Liberalism and Nationalism. In Wall, S. (ed.), The Cambridge Companion to Liberalism: Cambridge Companions to Philosophy (pp. 1-39). Cambridge: Cambridge University Press. 
Le Febvre, H. 1991. The Production of Space. Translated by Donald Nicholson-Smith. Cambridge: Basil Blackwell, Inc.

Li, Xiaorong. 2006. Ethics, Human Rights and Culture Beyond Relativism and Universalism. New York: Plagrave MacMillan.

Locke, J., 2003. Two Treatises of Government. In Shapiro, I. (eds.), Two Treatises of Government and A Letter Concerning Toleration (pp. 1-210). New Haven: Yale University Press.

Macpherson, C. B. 1964. The Political Theory of Possessive Individualism: Hobbes to Locke. Oxford: Oxford University Press.

Mann, B. 2014. Sovereign Masculinity: Gender Lessons from the War on Terror. Oxford: Oxford University Press.

Sabanadze, N. 2010. Globalization and Nationalism: The Cases of Georgia and the Basque Country. Budapest: Central University Press.

Said, E. W. 1993. Culture and Imperialism. New York: Knopf.

Skoll, G. R. 2016. Globalization of American Fear Culture: The Empire in the Twenty-First Century. New York: Palgrave Macmillan.

Smith, A. D. 1988. The Ethnic Origins of Nations. Malden, MA: Blackwell Publishing.

Tuck, R. 2002. The Rights of War and Peace: Political Thought and the International Order from Grotius to Kant. Oxford: Oxford University Press.

Tully, J. 1993. An Approach to Political Philosophy: Locke in Contexts. Cambridge: Cambridge University Press.

Tully, J. 2008. Public Philosophy in a New Key: II, Imperialism and Civic Freedom. Cambridge: Cambridge UP.

Wilson, W. 1918. Address of the President of the United States: Delivered at a Joint Session of the Two Houses of Congress, January 8. In United States. President (1913-1921: Wilson). Washington: Govt. print. off. 